\title{
The extent of financial disclosure and its determinants in an emerging capital market: the case of Egypt.
}

HASSAN, O.A.G., GIORGIONI, G. and ROMILLY, P.

2006 
The extent of accounting disclosure and its determinants in an emerging capital market: the case of Egypt

\author{
Omaima Hassan, Gianluigi Giorgioni \\ and Peter Romilly
}

Third draft: March 2005

\begin{abstract}
This paper uses panel data to investigate the extent and determinants of disclosure levels of non-financial companies quoted on the Egyptian Stock Exchange. Results show gradual increases in disclosure levels, with a high compliance for mandatory disclosure, although the voluntary disclosure level was rather limited. Public sector companies appear generally to disclose less information than private sector companies in terms of the layout of the balance sheet, cash flow statement, notes to accounts, policies adopted in preparing the financial statements, and general information. Furthermore, more profitable companies disclose more information than less profitable ones. Results for firm size, gearing and stock activity are mixed.
\end{abstract}

Key words: Mandatory disclosure; voluntary disclosure; Egypt; emerging market; panel data.

Address for correspondence

Omaima A. G. Hassan

Division of Accounting \& Law

Dundee Business School

University of Abertay Dundee 
Old College, Bell Street

Dundee DD1 1HG

United Kingdom

Tel. 0044-1382-308138

Fax. 0044-1382-308400

E-mail: 0016338@abertay.ac.uk

dbtoh@abertay.ac.uk

Dr. Gianluigi Giorgioni, Senior Lecturer in Economics and Finance, School of Accounting, Finance and Economics, Liverpool John Moores University.

G.Giorgioni@ljmu.ac.uk

Dr. Gianluigi Giorgioni is a Senior Lecturer in Economics and Finance at Liverpool John Moores University after having spent six years as a Lecturer in Economics at the University of Abertay Dundee. Dr. Giorgioni received the Laurea from Bologna University and his M.Sc. and Ph.D. from Liverpool John Moores University. He has published articles in journals such as Applied Economics, Applied Economic Letters, Economic Modelling, International Review of Applied Economics and the Journal of Chinese Economic and Business Studies. His research interests are in the areas of finance, international finance, applied macroeconomics and development economics.

Dr. Peter Romilly, Reader in Economics, Dundee Business School, University of Abertay Dundee. 


\section{Introduction}

This paper investigates accounting disclosure practice and its determinants for a sample of Egyptian non-financial companies listed in the Egyptian Stock Exchange (ESE) over the period 1995-2002. It contributes to the disclosure literature by using a panel data set. Panel data sets possess a number of advantages over traditional crosssectional or time series data sets. They usually give the researcher a large number of observations, increasing the degrees of freedom and reducing the collinearity problem among explanatory variables, hence improving the efficiency of econometric estimates. Moreover, the use of panel data provides a means of resolving or reducing the magnitude of the problem of omitted variables that are correlated with explanatory variables [1]. Furthermore, this paper distinguishes between disclosure practice for public business sector companies and private sector companies, and for heavily traded and less traded companies. These two characteristics are country related characteristics and hence improve our understanding of disclosure practice in Egypt.

Although the ESE is one of the oldest stock exchanges in the world, there appears to be virtually no comprehensive empirical international published study that covers disclosure practice in the Egyptian context, with the exception of the Abd-Elsalam and Weetman (henceforth AW) study in 2003 [2]. The purpose of the AW study was to investigate issues related to familiarity and language accessibility of the International Accounting Standards (IAS) disclosures when they were first introduced in the Egyptian capital market, while the purpose of this study is to investigate the extent of disclosure and its determinants for a sample of Egyptian listed companies. The AW disclosure index covers mandatory disclosures, while this research constructs two indexes covering both types of disclosure: mandatory and voluntary 
disclosures. The research sample in the AW study consists of 72 non-financial listed companies for the financial year 1995, while the sample in this study includes 77 companies spanning the period 1995 to 2002, thus enabling a panel data analysis.

The importance of this study arises from the benefits it provides to individual investors and regulators. The disclosure practices of the Egyptian listed non-financial companies may benefit individual investors when planning their investment choices in Egypt. Identifying variables affecting disclosure levels and shedding light upon the difference between public business sector companies and private sector companies regarding disclosure practice might help regulators in specifying ways to enhance disclosure and transparency in the ESE. Moreover, this study may help as a guide in studying other markets in the area, which may contribute to the accounting literature on emerging capital markets.

The rest of this paper is organised as follows. Section 2 provides a background to the ESE. The disclosure index and its creation are explained in section 3. Section 4 develops the research hypotheses. A description of the data, together with data analysis and results, are provided in section 5. Finally, section 6 summarizes the main conclusions. 


\section{An overview of Egypt's stock exchange and financial disclosure reporting}

Egypt is an Arabian, middle-eastern, and African country. These characteristics give this study a special importance, as the results could be applicable to a wide range of countries. The ESE is one of the oldest stock exchanges in the world, and the first one to be established in the Middle East. The Alexandria Stock Exchange was officially established in 1888 followed by Cairo in 1903. The ESE ranked fifth in the world in the 1940s. Historically, the performance of the ESE has reflected the economic changes that have taken place in modern Egypt's history. From this point of view, it is possible to identify four stages in modern Egyptian economic history: the pre-1956 period, the period between 1956 and 1973, the period between 1974 and 1991, and from 1992 to the present. The pre-1956 period was characterised by the dominant role of the private sector and witnessed the establishment and development of the ESE. By the middle of the 1950s the government adopted socialist oriented policies. This period witnessed the development of the public sector whilst the role of the private sector diminished. In 1974 the government adopted the Open Door Policy, which encouraged foreign investment in Egypt as a way to activate and enhance the role of the private sector in the economy. A number of new laws were issued to encourage and regulate the formation of private sector companies. Among those, the issuance of Tax Law no. 157 and Companies Law no. 159 in 1981 contributed to the increase in the number of companies listed on the Stock Exchange by both obliging joint stock companies to be listed on the Stock Exchange and offering tax exemptions for listing $[3,72-76]$. 
In 1990, the government started a program of economic reform and restructuring towards a free-market economy. The corner stone to a free-market economy was to adopt a privatisation program. The issuance of the public business sector companies' Law 203 of 1991 was the primary step in the privatisation program. According to this Law, public sector institutions previously subject to Law 97 of 1983 became holding companies. Companies that were under the supervision of these public sector institutions became subsidiary companies. The privatisation program started in 1994 when the government designated 314 public sector companies as potential candidates for the privatisation process. By the listing of state owned companies, the stock exchange witnessed the listing of two types of companies in terms of legal form: private sector companies and public business sector companies.

Public business sector companies must comply with the Uniform Accounting System (UAS) of 1966. The UAS was established for national planning and control purposes. It requires companies to prepare some accounts that are different from the traditional ones. Generally, according to the UAS public business sector companies are required to prepare a balance sheet, a profit and loss account, a production and trading account, a current production account, a statement of changes in financial position, and a cash flow statement. Moreover, public business sector companies listed in the ESE are joint stock subsidiary companies; hence they are obligated to comply with the disclosure requirement of Company Law (CL) of 1981. According to this Law, companies are required to prepare a balance sheet, a profit and loss account, and a board of directors' report. Furthermore, public business sector companies if listed in ESE have to comply with the disclosure requirements of the Capital Market Law (CML) 95 of 1992. According to the CML listed companies are required to comply 
with the Egyptian Accounting Standards (EAS) issued by the Ministry of Foreign Trade in conformity with the International Accounting Standards (IAS) / Financial Reporting Accounting Standards (IFRS). In the absence of specific EAS regarding any accounting treatment, the IFRS must be applied [4]. However, some overlap between the disclosure requirements of the three regulations does exist, especially between the disclosure requirements of $\mathrm{CL}$ and $\mathrm{CML}$. The disclosure requirements for private sector companies are organised according to the CL. However, all listed companies irrespective of their legal form, have to comply with the disclosure requirements of CML.

\section{The disclosure index}

The extent of accounting disclosure Marston and Shrives ( check reference list) [5] in the Egyptian context might not be empirically extensively researched before AbdElsalam [3]. She indicated that the level of compliance with Capital Market Law disclosure requirements in a sample of 72 Egyptian listed companies was $79 \%$ in 1995.

Moreover, the 2002 annual report of the Capital Market Authority [6] (CMA) and the Report on the Observance of Standards and Codes (ROSC) - Accounting and Auditing - note that there are gaps between official accounting standards and actual practices. A review of 2001 financial statements of the 30 top-listed companies revealed a number of missing disclosures [7]. 
This raises a question about compliance and non-compliance costs. From a company point of view, compliance costs include information production and dissemination costs, which include training preparers on the applicable standards. Non-compliance costs include market pressure and administrative penalties from CMA such as monetary penalties and delisting. With respect to non-compliance costs, many investors in Egypt are small investors who cannot form a pressure group on listed companies, unlike their counterparts in developed markets [3]. Administrative penalties by CMA were introduced in August 2002. Therefore, they were not applicable during the time period covered by this research. This was confirmed from the ROSC report [8], which indicates that the lack of knowledge among preparers and auditors of financial statements, the unavailability of implementation guidelines on EAS and IFR, and the lack of authority for enforcing penalties constrain the preparation of financial statements in compliance with the applicable standards. Generally, it appears that compliance costs might have exceeded non-compliance costs for listed companies at least for the time period investigated here. This leads us to expect a departure from full compliance with mandatory disclosure, which is not unique to the Egyptian companies as it was also observed in other emerging markets; examples are Nigeria, Hong Kong, and Bangladesh [9].

Therefore, to study disclosure levels in an environment that could be characterised as a low informational environment, it is believed that mandatory disclosure could form the basis of this study. The research method used here is a disclosure index [10]. We started with a list of items of information drawn from the checklist for the disclosure and transparency requirements of the CMA, which provides Guidelines Manuals to inform companies issuing financial securities and their auditors of the procedures 
followed by the CMA to ensure their compliance with disclosure and transparency requirements according to the EAS that are in conformity with IFRS.

A careful review of disclosure literature was undertaken to select items of information (not included in the checklist of the CMA) that Egyptian companies might disclose voluntarily. In a situation where full compliance with mandatory disclosure is not expected, this was a hard task.

We believe that the check list, used by the Center for International Financial Analysis and Research (CIFAR) [11] to evaluate corporate disclosure levels for leading industrial companies in a number of emerging and developed countries, was a reasonable one to start with. It includes some fundamental information that sometimes overlaps with the mandated one by CML. Hence, we can use it as a basis for the potential voluntary information index in the Egyptian context. Although the CIFAR database goes back to the middle ninetieths, it is still being used in recent accounting, finance and economics literature (see for example [12]).

Since, it could be argued that the list of items of information drawn from the CIFAR checklist are outdated or irrelevant to the Egyptian context, the list was then revised by checking out what companies did actually disclose. For example, while it is required to disclose the unpaid amount of capital, firms tend to disclose the paid amount of capital. Another example is deferred tax: companies tend to give notes about taxation and leave a note that the amount of deferred tax is not practical to measure. Moreover, the amended list was sent out to a sample of Egyptian professional users to request their views regarding the usefulness of items of 
information included in the list. They were asked to indicate their views regarding the usefulness of these items of information in making investment decisions about a company's common shares. A five-point scale is used, ranging from 1 (not useful) to 5 (very useful). In results not presented here, the minimum score assigned was 2.5, which indicates at least a medium level of usefulness of the items of information included in the initial list for decision making in the Egyptian context.

Then we applied the list of items of information to the sample firms and filtered it for non-applicable items: items that were rarely disclosed or have never been disclosed by the sample firms over the research period of study. We required that the item of information included in the list had to be disclosed at least by $20 \%$ of the sampled firms over the period of study to be included. This process led to the elimination of 40 items of information from the original list (see Appendix 1). This process left us with a final list that includes 75 items of information with a minimum awarded usefulness of 3.2 from the survey.

We followed the un-weighted approach in creating the two indices as this study is a longitudinal study and the level of importance of each item of information could have changed over time and among different industries. Depending on the list of items of information, each item of information is scored according to its existence in the annual reports of the sampled firms. An item scores 1 if it is disclosed and 0 if it is not. The total un-weighted index is calculated as the total scores awarded to a particular company for a particular year divided by the maximum number of applicable items of information. 
Finally, assuming that low compliance with mandatory disclosure could be treated as voluntary disclosure, as more discretion is believed to be exercised over disclosing these items of information, we considered mandatory items of information disclosure that show volatility over time to be voluntary disclosure. To lessen subjectivity in doing so, we calculated the compliance ratio for each item of information included in the final list for the whole sample. The average score awarded to a particular item over the sample period measures the compliance ratio. For example, company name is disclosed from the whole sample so it is awarded a compliance ratio of 1 and so on. Figure (1) shows the compliance ratio for each item of information included in the final list for the whole sample.

Graph 1 is about here

From this Graph we notice that mandatory items of information, which are presented by a continuous line from 0.20 to 1 , exhibit different levels of compliance. A number of mandatory items of information have high compliance levels. Some of them have low compliance levels, however, and show levels of compliance that are very similar to those of voluntary items of information. Hence, as shown in Graph (1) we were able to identify a "cut" point. It is the point at which we treat low compliance with mandatory disclosure as voluntary disclosure. From Graph (1) this cut point is a compliance ratio of $78 \%$. Above this cut point are mandatory items of information, which have high compliance ratios; hence they form the mandatory disclosure index. Under this cut point are mandatory items, which have low compliance ratios, and voluntary items of information; hence they both form the voluntary disclosure index. 
It is worth noting that the first item under the cut point is a voluntary item of information, which indicates that the cut point is a reasonable one.

In brief, items that have a compliance ratio from $78 \%$ and above are considered to form the mandatory disclosure index (49 items of information), and the rest are voluntary disclosure (26 items of information). Hence we create the two indices: mandatory disclosure index and voluntary disclosure index (see Appendix 1).

\section{Development of hypotheses}

Expectations about determinants of disclosure levels depend on a review of prior studies. Prior studies rely on a framework of agency theory and signalling theory to develop their hypotheses regarding determinants of disclosure levels. Given a separation of ownership and control of resources in a firm, agency theory predicts conflicts between shareholders (principal) and managers (agent) and between shareholders/managers (agent) and debt-holders (principal) to take place within the firm if individuals act self-interestedly. Two sets of agency costs are then incurred: the agency cost of equity or debt and the costs of monitoring managers, so that managers do pursue the principal's interest [13]. Depoers [14, 248] added 'given that these costs (monitoring costs) reduce their compensation, managers have an incentive to keep them low. Since accounting disclosure is a means by which their activity can be monitored, managers are thus encouraged to disclose information voluntarily'.

Signalling theory is concerned with the information asymmetry problem between managers of the firm and the market. Abd-Elsalam (Check this passage, reference to 
Gujarati should be eliminated. Also add page number of this quote) $[3,28]$ stated that: 'signalling theory, in the disclosure scenario, means that managers will disclose information which implies that the company has a share value which is larger than that assessed by the market, in order to encourage an upward revision of their stock prices. Managers will withhold information that implies values below the assessment of the market. These "silent" companies are identified by investors as companies with less than average valuation and, accordingly, their shares will be re-valued downward. This downward price revision of non-disclosing companies will in turn encourage those within the group holding good news, relative to the recently decreased average valuation, to screen (signal) themselves out of the group by disclosing their information. The disclosure process thus proceeds, until the positions of all companies in the valuation hierarchy are identified'.

Prior studies on disclosure levels have examined the relationship between a measure of the disclosure level and/ or quality and a number of company characteristics: company size, listing/cross listing, profitability, gearing, and others. While the results for firm size and listing/ cross listing are most often constant among prior studies, other variables yield mixed results.

In the following section we develop hypotheses about the relationship between disclosure levels and firm characteristics: firm size, legal form, profitability, gearing and stock activity, which might affect disclosure levels in the Egyptian context. 


\subsection{Firm size}

A large number of prior studies investigate the relationship between disclosure level and firm size. Firm size is considered to be an important determinant of corporate disclosure strategy and is used as a control variable in the empirical literature on disclosure. Results frequently confirm a positive relationship between firm size and disclosure level. Prior studies provide a number of explanations of this positive effect of size upon disclosure level. It is argued that firm size is a comprehensive variable that could proxy for competitive advantages, information production costs and political costs $[3,43]$. Firstly, information production and dissemination is a costly process, and larger firms might be more able to afford these expenses. Also, if the process of producing information includes a fixed component, the proportion of these fixed costs to firm size will be smaller for larger firms. Secondly, more disclosure might put smaller companies in a position of competitive disadvantage with their larger counterparts in the industry. Therefore, they might be reluctant to disclose more information than larger companies. Thirdly, large companies are more likely to be in the public eye and attract news coverage and public interest, and are more closely monitored by government agencies; hence they might disclose more information to reduce public criticism or government involvement in their affairs. Moreover, it is argued that the larger the company (in terms of number of shareholders), the larger the informational gap (information asymmetry) among investors on one hand and between investors and the management on the other hand, so more disclosure might be used to reduce the information asymmetry problem.

While most prior studies support the hypothesis that large firms disclose more information than small firms, Ahmed and Nicholls [9] found a negative but not 
significant relationship between firm size and mandatory disclosure. Moreover, AW found no significant association between different measures of mandatory disclosure (IAS) for a sample of Egyptian listed companies and firm size at the 5\% level of significance in a univariate analysis. As prior empirical studies in the Egyptian context are rare and AW could not support or dismiss a positive relationship between firm size and disclosure level, we will test for the general expectation regarding the effect of firm size. Hence we can develop the first hypothesis as follows:

H1: Larger firms are expected to have higher levels of disclosure than that of smaller firms.

Although there are a number of measures of firm size, including number of shareholders, shareholders' funds, total assets, total sales, and market value of equity, the disclosure literature does not provide a theory or criterion to choose among different proxies. However, total assets and sales were the most popular measures of firm size in prior studies. Therefore, we use the book value of total assets and sales respectively.

\subsection{Legal form}

This attribute is particularly relevant to Egyptian listed companies as they can be classified according to their legal form into two types: private sector companies and public business sector companies. Public business sector companies are state owned companies, which have been listed in the ESE in preparation for full privatisation. 
Although both types of business might comply mainly with different financial reporting requirements according to different laws as explained in section 2 , if they are listed in the ESE then they must comply with the Egyptian Accounting Standards (EAS) issued by the Ministry of Foreign Trade in conformity with the International Financial Reporting Accounting Standards (IFRS). In the absence of specific EAS the IFRS must be applied. However, AW hypothesized that public sector companies are more likely to disclose more information than private sector companies and provided some explanations. Public business sector companies were among the largest listed companies, so this variable could proxy for firm size (agency theory). Also they are listed for privatization purposes, so because they seek finance, they may disclose more information (capital need theory). Moreover, public sector companies are subject to close observation by the government and the public, so they might disclose more to reduce political costs. AW found a significant positive association between legal form and two measures of mandatory disclosure level [15] (IAS-CA, IAS-NA), but no significant association was found with IAS-CML.

However, if the hypothesis of the large size of public sector companies was applicable in 1995, we do not expect it to be applicable from 1995 to 2002, as more public sector companies were privatized over this period of time and some large private sector companies were listed after 1995. Moreover, the hypothesis of seeking finance holds for both private sector companies and public business sector companies in our sample, as both are public companies, and family companies are excluded from the research sample. Furthermore, the hypothesis of political costs could hold for both types of company as more attractive private companies, especially for small investors who lack experience, have entered the market particularly in the communication sector. In 
brief, while the hypotheses of AW might hold for their sample period, they might be less applicable to our sample construction and period of study. From this discussion we do not expect a significant difference in disclosure levels between these two types of companies to exist. Hence, the hypothesis to be tested is:

H2: legal form does not affect levels of disclosure of listed companies.

Legal form is measured using a dummy variable that takes the value of one if the company is a public sector one and zero if not.

\subsection{Profitability}

Prior studies predict that the relationship between profitability and disclosure is positive. Several explanations have been offered for this expectation. First, managers of more profitable companies are motivated to disclose more to distinguish their companies from less profitable ones (good news-signalling theory), in order to increase investors' confidence, and to obtain personal advantages such as continuance of their positions and boosting their compensation. Second, according to political process theory more profitable companies will disclose more to justify their levels of profits [16]. However, signalling theory predicts that managers might choose to disclose bad news in a timely manner to reduce the risk of legal liability and/or loss of reputation [17]. It is obvious that while agency theory and political process theory predict a positive association between profitability and disclosure level, signalling theory provides justification for a negative relationship. Empirical studies also 
provide contradictory results for example AW found positive and negative but not significant relationships between profitability and mandatory disclosure levels. In brief, both theoretical and empirical prior studies indicate the possibility of both positive and negative relationships. However, in the Egyptian context, it was suggested that investors are more interested in the profit figures [18, 19]. Assuming that listed companies are aware of investors' interest, we can expect that more profitable companies will disclose more to increase investors' confidence. Hence, we can develop our third hypothesis:

H3: the higher the level of profit the company achieves, the higher the level of information it discloses.

Profitability is measured as net income to book value of equity.

\subsection{Gearing}

Gearing is a measure of the ability of a company to meet its obligations either in terms of long-term debt or total debt. It is argued that the higher the gearing ratio, the higher the agency costs because larger gearing ratios allow for greater potential transfer of wealth from creditors to shareholders [14, 249]. Hence highly geared companies encounter more monitoring costs and have greater obligation to satisfy the information needs of debt-holders. So they are likely to disclose more information than lowly geared companies. This in turn should reduce the monitoring costs (agency theory) of long-term debt-holders. Results from prior studies regarding the relationship between gearing and disclosure level are contradictory. Chow and Wong- 
Boren [20] found no significant effect. AW found a significant negative relationship between gearing and their measure of mandatory disclosure level (IAS-CML), while no significant association was found with their other measures of disclosure level (IAS-CA, IAS-NA).

However, the bond market in Egypt is very small compared to other emerging and developed capital markets. It represents around 15.5 percent of the total market capitalization as of the end of June 2002. Bondholders' associations have the right to inspect the financial statements and to send a representative to the annual general meeting. Accordingly, the main borrowing facility by the Egyptian listed companies is still borrowing from banks and holding companies, especially for the sample firms where there was no single company that has issued bonds. Given that we expect the number of debt-holders of a particular company to be small, they should gain easy access to the information they need directly from the company. Thus we do not expect that gearing ratio will affect disclosure level in the annual reports.

The hypothesis to be tested is that:

H4: the level of information disclosed by a firm is not associated with the level of its gearing ratio.

Gearing is measured as total debt to total assets. 
Companies listed in the ESE can be classified into traded companies and rarely traded companies. Rarely traded companies are in most cases family companies, which are listed to exploit the tax exemptions applied to listed companies. AW hypothesized that traded companies are likely to disclose more than rarely traded companies as they seek finance. AW found a significant positive association between their measure of stock activity and two measures of mandatory disclosure (IAS-CA, IAS-CML) but no significant association was found with their third measure of mandatory disclosure (IAS-NA)

Although our sample consists of traded companies only, we can distinguish between heavily traded companies and less traded companies. Heavily traded companies are in the public eye to a greater extent with greater news coverage than less traded companies (political process theory), so they might disclose more information than less traded companies. Moreover, if the information asymmetry problem exists for heavily traded companies, they then might face a risk of undervaluation of their stocks in the market. Hence, managers of firms that perceive their firm's share value as larger than that assessed by the market, are motivated to disclose more information to encourage an upward revision of their stock prices (signalling theory). Hence, the hypothesis to be tested is:

H5: heavily traded companies are more likely to disclose more information than less traded companies. 
Stock activity is measured as the ratio of the number of trading days during the six months prior to the financial year-end to total trading days during that period.

\section{Data analysis}

\subsection{Data collection and sources}

This section describes the process of collecting the relevant data used in this research. The objective was to collect a complete series of annual reports in their original format for as many traded non-financial companies as possible over the period 1995 to 2002 [21]. After contacting some potential sources, the Capital Market Authority (CMA) in Egypt proved to be the most suitable source for this information. The electronic archive department, which is part of the information centre, scans the original reports of listed companies. This process considerably facilitates the access to these reports for a wide range of users including researchers and investors.

The final sample consists of 77 non-financial listed companies from 13 different industrial sectors over the period 1995 to 2002 . We reached this figure after a number of refinements due to changes in legal status, ownership and availability of data. We started with 66 non-financial listed companies about which information is available. However, thirteen of these companies have been privatised and changed their legal form from public sector companies to private sector companies, and two other companies have merged. It was decided to treat these fourteen companies as new companies once the change had taken place, thereby avoiding any overlap of data 
from prior periods. This yielded 80 cross sections. The number of observations per company varies ranging from one to eight observations over the period 1995 to 2002 [22]. Finally, three companies in the sample did not start production during the sample period, so that information about profitability was not available. Hence they were dropped from the analysis leaving 77 companies with 264 final observations (cross-section and time series).

\subsection{Preliminary descriptive analysis of the variables}

Table (1) provides a descriptive analysis of each variable. The average size of firms measured by total assets is L.E 572 million, while the average size measured by sales is L.E 323 million. The sample consists of 123 public business sector observations and 141 private sector observations. Average profitability is $28 \%$, and average gearing ratio is $58 \%$. Companies in the sample are on average heavily traded companies as they were traded $82 \%$ of the possible days of trading.

Table 1 is about here

On average, listed non-financial Egyptian companies publish $90 \%$ of the list of mandatory information items (49 items) and $48 \%$ of the list of the voluntary information items (26 items). These results are similar to those obtained in the Saudi market [23] where the average compliance with mandatory disclosure was 0.93 , but higher for the average of voluntary disclosure which was 0.28 in the Saudi market. As almost all the variables are skewed, a logarithm transformation of the variables was 
undertaken to bring the distributions of these variables closer to normality [24]. Using the natural logarithm of each variable, however, the transformation was only successful with the book value of total assets, as can be seen from Table (1). Hence we use the natural logarithm of total assets rather than sales as a measure of firm size in the subsequent analysis.

Graph (2) shows trends in the level of the different types of information disclosure over time. It shows an increasing rate of compliance with mandatory disclosure (Med Mindex). This high level of compliance confirms the compulsory nature of this list of information over time. However, departing from full compliance might reflect that compliance costs for listed companies exceeded non-compliance costs over the sample period. But this should change after the introduction of the new listing rules, which took place in August 2002, as more non-compliance costs, which vary from monetary penalties to delisting, are incurred. The level of voluntary disclosure (Med Vindex) is increasing over time apart from the decline in 1997. This particular decline in voluntary disclosure will be tested later on.

\section{Graph 2 is about here}

Since the normality hypothesis is rejected for almost all the variables except $\ln$ (assets) and gearing a nonparametric correlation test is used. The Spearman cross product correlation matrix is presented in Table (2). 
Using Table (2) we can examine the correlation between different proxies of disclosure level and their expected determinants as well as the correlations among the explanatory variables to check whether there is any potential sign of multicollinearity. While the results confirm some statistically significant correlations among the explanatory variables, the magnitude of these correlation coefficients, which do not exceed 0.362 , do not indicate a serious collinearity problem [25].

Table 2 is about here

As a further check for multicollinearity the variance inflation factor (VIF) is computed for each independent variable in the multiple regression model by regressing each explanatory variable on the rest of the explanatory variables in individual multiple regression models using SPSS software (results not presented here). The VIF does not exceed 1.1 for any explanatory variable. It is considered that for a particular explanatory variable collinearity is not a problem if the VIF for that variable is less than $5[26,576]$. This is confirmed from the tolerance coefficients [27], which did not fall below 0.905 for any independent variable. We conclude that collinearity is not a problem for our model.

In terms of the correlation coefficients reported in Table (2), the correlation between voluntary disclosure and firm size is positive and significant at the $5 \%$ level of significance (one tailed test) as expected. However, the correlation between mandatory disclosure and firm size is negative and significant. Furthermore, the 
correlation between legal form and voluntary disclosure is significantly negative, while it is insignificantly positive with mandatory disclosure. This in turns means that while there is no difference between public business sector companies and private sector companies in terms of mandatory disclosure, public business sector companies disclose less voluntary information than do private sector companies. All the correlation coefficients between the other variables and the two measures of disclosure are not significant.

The negative and significant correlation between mandatory disclosure and firm size on the one hand, and the negative and significant correlation between legal form and voluntary disclosure on the other hand, require more detailed examination since they are not expected.

We start with the results for legal form. Since all listed companies have to comply with disclosure requirements irrespective of their legal form, the first step was to test whether there is any difference between public sector companies and private sector companies regarding other firm characteristics for example: size, profitability, and gearing that could have been captured by our legal form variable.

Therefore, we tested for differences in the mean of each firm characteristic and disclosure levels between public business sector companies and private sector companies. The results in Table (3) show that there is no significant difference between public sector companies and private sector companies regarding firm profitability, size, stock activity and mandatory disclosure level. However, public 
sector companies do tend to have higher gearing ratios than private sector ones and tend to disclose less in terms of voluntary disclosure.

Table 3 is about here

We suggest a number of potential explanations for the higher gearing ratios and the low voluntary disclosure. First, public sector companies may have a higher gearing ratio because they tend to borrow from banks and holding companies that are stateowned. Both types of lenders should have easy access to information whenever required. Moreover, effectively this debt of public sector companies is backed by the state. Therefore, it is conceivable that public sector companies might feel under less pressure to disclose information to public on a voluntary basis. Second, our panel of companies includes thirteen public sector companies that have been privatised and changed their legal form to private sector companies. It was decided to treat these thirteen companies as "new companies" once they changed their legal status. It is possible that these companies, once successfully privatised, were more inclined to disclose information than other public sector companies that have not been privatised

Third, public sector companies and private sector companies are effectively complying with different sets of regulations, thus potentially creating some room for confusion. During our investigation of the annual reports of the sample firms, we noted that public business sector companies disclose information according to the disclosure requirements of the Uniform Accounting System (UAS) in most cases, while private sector companies, where state ownership is less than $51 \%$, disclose 
information according to the disclosure requirements of the UAS, the Company Law (CA) of 1981, and the Capital Market Law (CML) in most cases. Private sector companies usually disclose information according to the disclosure requirements of the CA or/and the CML. Given that the list of information disclosure comprising the disclosure indexes of this research is primary reflecting the disclosure requirements of the CML which in turn has some overlap with the disclosure requirements of the CA of 1981; it is not surprising that public business sector companies disclose less information than do private sector companies. Moreover, it is worth noting that CMA staff was using standard forms for the balance sheet (statement of financial position) and profit and loss account (income statement), which are very similar to their counterparts according to the Company Law of 1981, to fill in and keep records of disclosure information on listed companies. However, it seems that listed companies were not obligated to release their annual reports using these forms.

This led us to investigate the difference in financial reporting practice per item of information between public business sector companies and private sector companies. The results in Appendix (3) present the T-test for equivalence in the mean for each item of information according to the legal form of the reporting entity. The disclosure index contains 75 items. Of these, 31 items of information reflect no significant difference in the mean according to the legal form of the reported company. Of the remaining 44 items, the results show that public business sector companies disclose more information for 17 items than do the private sector ones, but disclose less for 27 items of information. 
In terms of mandatory disclosure, public sector companies disclose less in 14 cases out of 23, while in terms of voluntary disclosure public sector companies disclose less in 13 out of 21 .

A more detailed analysis in Appendix 3 show that public business sector companies disclose more details regarding some items of information than private sector ones such as: classification of other receivables, provisions, long-term liabilities, investments in projects under construction, other investments and their market values if different from book value, operating income, interest expense, non-operating revenues and expenses, financial ratios, foreign exchange gains / losses, composition of shareholdings, cash outflow for taxes, number of employees, business segment, exports, composition of shareholdings and significant shareholders. However, they disclose less regarding the layout of the balance sheet, cash flow statement, notes to accounts, policies adopted in preparing the financial statements, and other information such as: EPS information, company legal status, purpose of the company's activity, number of issued shares and par value per share and restrictions on ownership of assets.

These results provide some support for our hypothesis of lack of a standard form for the annual report, which might lead public business sector companies in most cases to disclose according to the Uniform Accounting System (UAS) of 1966 rather than to disclose according to the Capital Market Law no. 95 of 1992.

To try to explain the negative relationship between firm size measured by $\ln$ (assets) and mandatory disclosure levels we divided the sample of companies into two groups according to their size: larger or smaller than the median asset size. The results, not 
presented here for reasons of space, show that only for seven out of 49 items of mandatory information is there a significant difference in their mean value. Smaller firms disclose more information regarding five items: 1.6, 2.3, 2.8, 3.19 and 7.5, while large companies disclose more information regarding two items of mandatory information: 3.12 and 3.17. (proofs are right) However, it is possible that the negative relationship is due to the disproportionate effect of very big companies, This prompted us to examine the dataset in the subsequent analysis for outliers, defined as observations with large standardized residuals (equal to or more than 3 standard deviations), and/or observations whose values give them large influence . In the following section based on a multivariate analysis we will show results based on a sample that includes the outliers and one that excludes them. However, the removal of outliers did not affect the relationship between size and mandatory disclosure. 


\subsection{The multiple regression model}

We estimate multiple regression models specified according to the hypotheses developed in the previous section for all variables expected to affect disclosure levels.

The general regression model to be estimated is:

Disclosure level $=f$ (firm size, legal form, profitability, gearing, stock activity)

We add a dummy variable for 1997 in the voluntary disclosure model because it is shown from the descriptive analysis that the voluntary disclosure level dropped in 1997. In 1997 Egypt witnessed three major events: a terrorist attack on upper Egypt in November 1997, which affected the whole economy for some years; the issuance of the Egyptian Accounting Standards by the Ministry of Foreign Trade, which should facilitate the preparation of mandatory disclosure information; and finally the introduction of symmetric price limits $(-5 \%$ to $+5 \%)$ on individual shares on February 24, which might be responsible for price distortions on the Stock Exchange. While the issuance of the EAS could enhance mandatory disclosures, as more guidelines are available, the other two events could give contradictory expectations regarding the level of voluntary disclosure. However, we test for a negative effect guided by the descriptive analysis.

Multiple regression models are estimated for both types of disclosure level: voluntary and mandatory. The method of estimation used was pooled-generalised least squares (GLS), with White heteroskedasticity-consistent standard errors and covariance. 
Heteroskedasticity is an issue, given that different sizes of companies are included in the sample. E-Views software was used to estimate the models. Using the White heteroskedasticity-consistent standard errors and covariance option, E-Views estimates covariances that are robust to general heteroskedasticity. This panel data form of heteroskedasticity is different from pure cross-section heteroskedasticity, since variances within a cross-section are allowed to differ over time. GLS is ordinary least squares (OLS) estimation on transformed variables that satisfies the standard least-squares assumptions [28, 363]. GLS gives less weight to observations with greater variability and more weight to observations with smaller variability, so it enables us to estimate the population regression function more accurately. The standard OLS method does not follow this strategy and therefore does not make use of the "information" contained in the changing variability of the dependent variable [28, $362]$.

Regression results for both mandatory and voluntary disclosure levels with and without outliers are presented in Table (4). With respect to the results without excluding the outliers, all the explanatory variables in the mandatory index regression are highly significant. The relationship between firm size and mandatory disclosure is significantly negative, which confirms the results obtained from the descriptive analysis. Significant negative relationships between both types of disclosure indexes and legal form are confirmed at the $1 \%$ level of significance. The results for profitability are mixed and contradict our hypotheses to some extent. While profitability and mandatory disclosure are significantly positively related as expected, it has no significant relationship with voluntary disclosure [29]. The results for 
gearing are significantly positive at the $1 \%$ level of significance for mandatory disclosure, but negative and not significant for voluntary disclosure. So, while higher gearing ratios are motivating companies to comply with mandatory disclosure, they do not affect voluntary disclosure. These results for gearing contradict our hypotheses with respect to the Egyptian market.

\section{Table 4 is about here}

The results for share activity are also mixed. While heavily traded companies are more likely to comply with mandatory disclosure, they are less likely to disclose information voluntarily. The dummy variable is significantly negative, implying that the events of 1997 significantly reduced the level of voluntary disclosure

The adjusted R-squared of each model is very high [30] compared to prior studies. The lowest adjusted R-squared obtained was for the voluntary disclosure model (0.89), but this is still very high compared with prior studies. However, the high value of the adjusted R-squared might not be sufficient to indicate how good the model is. Therefore, we also report the standard error of each model [31]. The standard error of each regression model is within an acceptable range, although we do not use the models for prediction in this paper.

As previously mentioned, as a robustness check of the sensitivity of our results to the existence of outliers, we have re-estimated the models after excluding the outliers. Then we apply GLS, with White heteroskedasticity-consistent standard errors and 
covariance to the modified data for each model. The results are presented in Table (4).

The results show that dropping the outliers does not affect the relationships between both types of disclosure and firm size, legal form, stock activity and the1997 dummy in terms of the sign and significance of the coefficients, although it does affect the magnitude of the coefficients to some extent.

However, dropping the outliers does cause all the profitability coefficients to become significant and positive bringing our results in line with with expectations from the agency theory and the political process theory.

Moreover, dropping the outliers completely changes the results for the gearing ratio: gearing now has no relationship with mandatory disclosure as previously expected with regard to the Egyptian market. However, gearing ratio has a significant negative relationship with voluntary disclosure, a results that runs against expectations derived from agency theory. . Given that highly geared companies are public business sector companies, this result confirm our prior expectations that those companies might be under less intensive pressure to disclose information voluntarily as their debt is mostly from state owned banks and holding companies.

\section{Concluding remarks}

This paper has investigated the extent of accounting disclosure and its determinants for Egyptian non-financial companies listed in the ESE. The importance of this 
research arises from using longitudinal data sets, which are rarely used in the disclosure literature. Moreover, this study investigates the difference between public business sector companies and private sector companies in terms of firm characteristics and disclosure practice.

Our results generally show gradual increases in disclosure levels for listed nonfinancial companies over the period 1995 to 2002. Large companies disclose more information in terms of voluntary disclosure, but they disclose less information in terms of mandatory disclosure. While the positive effect of firm size upon voluntary disclosure level is generally expected, the negative effect of size upon mandatory disclosure remains unexplained.

Public business sector companies disclose less information than private sector companies whatever the type of disclosure is. One possible explanation is that public business sector companies disclose information in their annual report in the fulfilment of the disclosure requirements of the Uniform Accounting System rather than the disclosure requirement of the Capital Market Law, which mainly forms the disclosure index of this research. Differences between public business sector companies and private sector companies do exist for different types of information. While public business sector companies disclose more financial details about some items of the balance sheet and income statement, they disclose less regarding the layout of the balance sheet, cash flow statement, notes to accounts, policies adopted in preparing the financial statements, and general information. These results call for a standard format for the annual report to enhance compliance with mandatory disclosure according to CML. 
Moreover, more profitable companies disclose more information than do less profitable ones. . The gearing ratio was found to decrease the level of voluntary disclosure, with no effect upon mandatory disclosure. Furthermore, while stock activity enhances compliance with mandatory disclosure, it makes companies more reluctant to disclose information voluntarily.

A potential limitation of studies using disclosure indices to investigate disclosure levels is that the results are only valid to the extent of the disclosure index used and time period investigated. The selection of the items included in the disclosure index, and the classification into mandatory and voluntary disclosure indices, inevitably involved some degree of judgement and subjectivity. Although we have tried to diminish subjectivity it cannot be removed entirely [5]. Also, due to missing data we were unable to test for fixed effects. Another limitation is that the research sample is not randomly selected. This is due to the difficulty of gathering data in an emerging country; hence availability of data limits our ability to select a random sample.

Future research could investigate the impact of new regulations upon the level of compliance with mandatory disclosure, as compliance costs will increase. Also future research might investigate the impact of other potential explanatory variables such as ownership structure and board composition, which are proxies for corporate governance, upon the level of disclosure. More research could be carried out to investigate disclosure levels using dynamic models. A comparative study of disclosure practice for different countries in the region complying with IFRS might also be fruitful. 
Graph 1 Disclosure indices

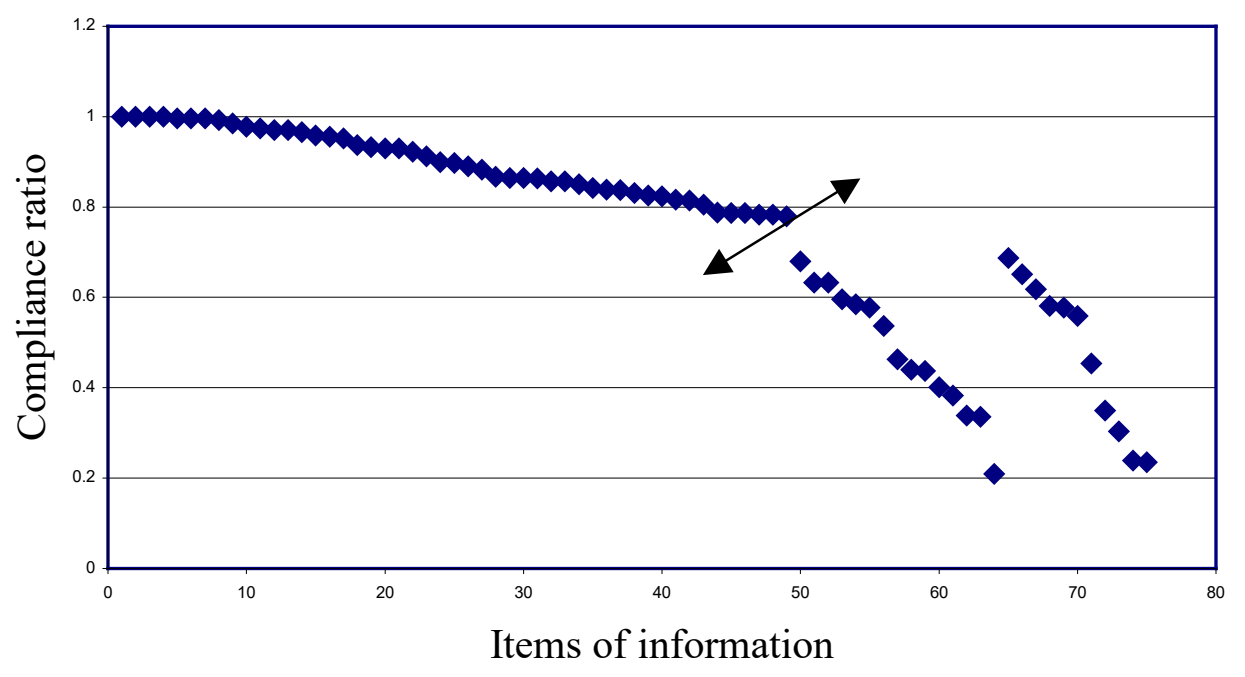

Table 1 Descriptive analysis - common samples

Gearing: total debt/ total assets; profitability: net income/book value of equity; stock activity: share trading days for six months after the financial year-end divided by total trading days.

\begin{tabular}{lcccccc}
\hline & Mean & Median & Maximum & Minimum & Skewness & Kurtosis \\
\hline Mandatory disclosure & 0.898 & 0.938 & 1 & 0.438 & -1.826 & 6.576 \\
Voluntary disclosure & 0.48 & 0.52 & 0.846 & 0 & -0.468 & 2.425 \\
Sales (LE) m & 323 & 180 & 2300 & 4 & 2.738 & 12.324 \\
Ln (Sales) & 19.038 & 19.008 & 21.556 & 15.237 & -0.49 & 3.259 \\
Assets (LE) $\mathrm{m}$ & 572 & 295 & 5990 & 18 & 3.725 & 21.175 \\
Ln (Assets) & 19.585 & 19.502 & 22.513 & 16.7 & 0.127 & 2.975 \\
Gearing & 0.584 & 0.588 & 0.947 & 0 & -0.283 & 2.632 \\
Profitability & 0.281 & 0.26 & 1.399 & -0.91 & 0.702 & 9.257 \\
Stock activity & 0.818 & 0.941 & 1 & 0.188 & -1.16 & 3.014 \\
\hline
\end{tabular}


Graph 2 Median disclosure levels over eight years

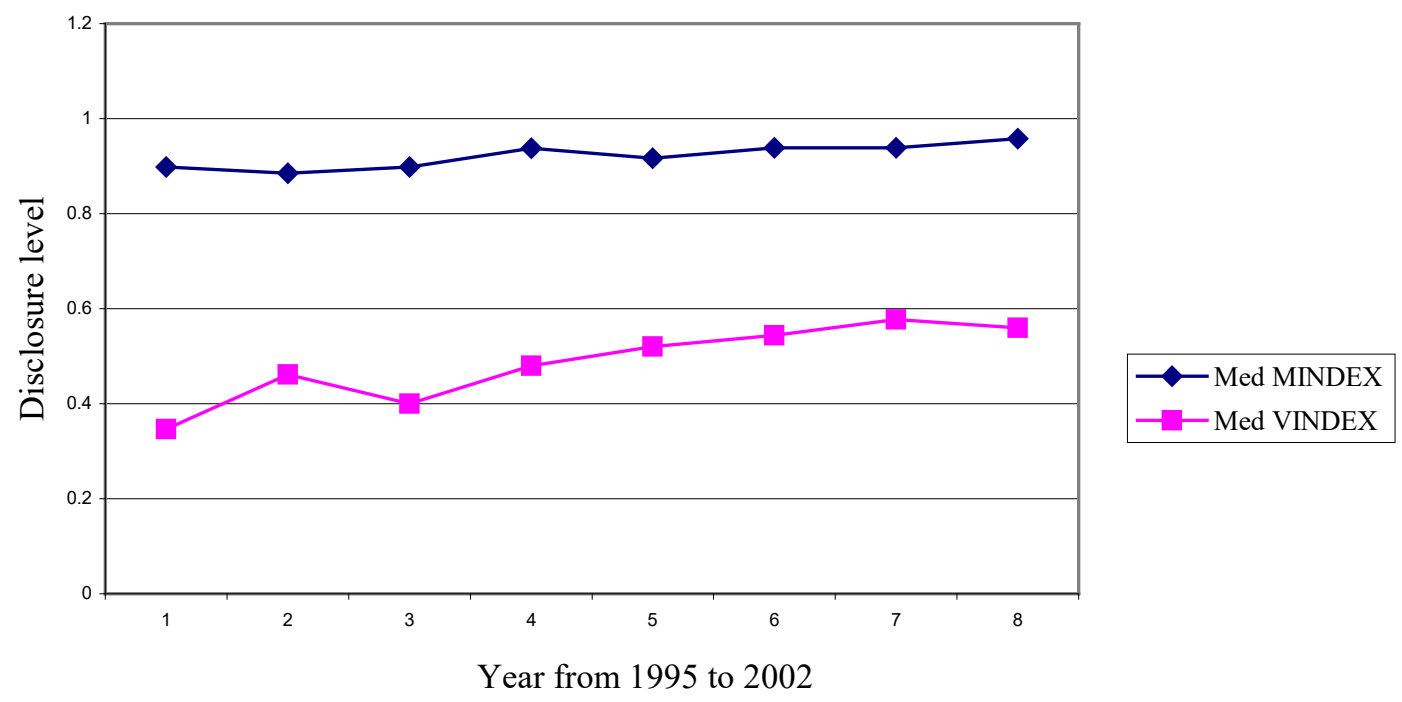

Table 2 Spearman's correlation coefficients

MINDEX: mandatory disclosure level; VINDEX: voluntary disclosure level.

MINDEX VINDEX Size $\begin{gathered}\text { Legal } \\ \text { form }\end{gathered}$ Profitability Gearing

\begin{tabular}{lccccccc}
\hline VINDEX & $0.554^{* *}$ & & & & & \\
& $(0.000)$ & & & & & \\
Size: & $-0.121^{*}$ & 0.102 & & & & \\
& $(0.047)$ & $(0.092)$ & & & & \\
Legal form & 0.006 & $-0.265^{* *}$ & 0.036 & & & \\
& $(0.921)$ & $(0.000)$ & $(0.513)$ & & & \\
Profitability & 0.064 & 0.007 & 0.081 & 0.019 & & \\
& $(0.299)$ & $(0.904)$ & $(0.138)$ & $(0.729)$ & & \\
Gearing & 0.020 & -0.029 & $0.118^{*}$ & 0.100 & $0.189^{* *}$ & \\
& $(0.748)$ & $(0.636)$ & $(0.027)$ & $(0.067)$ & $(0.000)$ & \\
Stock activity & -0.001 & -0.084 & $0.307^{* *}$ & -0.082 & $0.152^{*}$ & 0.079 \\
& $(0.984)$ & $(0.167)$ & $(0.000)$ & $(0.176)$ & $(0.013)$ & $(0.193)$ \\
\hline
\end{tabular}

Numbers in parentheses are probabilities of significance. ${ }^{* *}$ Significant at $1 \%$ level (2-tailed).

* Significant at $5 \%$ level (2-tailed). 
Table 3 T-test for equality of means

\begin{tabular}{|lccccc|}
\hline & \multicolumn{2}{c}{ Public sector } & \multicolumn{2}{c}{ Private sector } & T-test \\
\cline { 2 - 6 } & $\mathrm{N}$ & Mean & $\mathrm{N}$ & Mean & P. (2-tailed) \\
Mandatory disclosure & 123 & 0.895 & 149 & 0.899 & 0.763 \\
Voluntary disclosure & 123 & 0.428 & 149 & 0.526 & 0.000 \\
Size & 162 & 19.711 & 174 & 19.532 & 0.117 \\
Profitability & 162 & 0.270 & 164 & 0.277 & 0.816 \\
Gearing & 162 & 0.611 & 174 & 0.565 & 0.030 \\
Stock activity & 123 & 0.825 & 149 & 0.815 & 0.714 \\
\hline
\end{tabular}

The number of total observations per variable might be different among different variables than the total observations in the final sample (272 observations) due to the inclusion of comparable figures in previous years. 
Table 4 Multiple regression models

Dependent variables: voluntary and mandatory disclosure indices

Sample size: 77 companies for the period 1995- 2002

Firm size: natural logarithm of the book value of total assets; legal form: a dummy variable taking the value of one if the company is a public sector company and the value of zero otherwise; profitability: net income/book value of equity; gearing: total debt/ total assets; stock activity: share's trading days for six months after the financial year-end divided by total trading days; d1997: a dummy variable for year 1997. The number of observations decreases after eliminating outliers, defined as those observations with large standardized residuals (equal to or more than 3), or observations whose leverage values give them large influence. These outliers have been identified for each model individually; hence the number of observations in each model after dropping the outliers is different.

\begin{tabular}{|lcccc|}
\hline Variable name & \multicolumn{2}{c}{$\begin{array}{c}\text { Models before dropping the } \\
\text { outliers }\end{array}$} & \multicolumn{2}{c|}{$\begin{array}{c}\text { Models after dropping the } \\
\text { outliers }\end{array}$} \\
\cline { 2 - 6 } & $\begin{array}{c}\text { Voluntary } \\
\text { index }\end{array}$ & $\begin{array}{c}\text { Mandatory } \\
\text { index }\end{array}$ & $\begin{array}{c}\text { Voluntary } \\
\text { index }\end{array}$ & $\begin{array}{c}\text { Mandatory } \\
\text { index }\end{array}$ \\
Constant & 0.002 & $1.107^{* *}$ & -0.040 & $1.018^{* *}$ \\
Size & $(0.023)$ & $(59.437)$ & $(-0.522)$ & $(27.828)$ \\
& $0.032^{* *}$ & $-0.013^{* *}$ & $0.034^{* *}$ & $-0.007^{* *}$ \\
Legal form & $(8.331)$ & $(-12.922)$ & $(8.432)$ & $(-3.370)$ \\
& $-0.105^{* *}$ & $-0.013^{* *}$ & $-0.107^{* *}$ & $-0.008^{*}$ \\
Profitability & $(-10.159)$ & $(-5.411)$ & $(-10.482)$ & $(-2.445)$ \\
& 0.004 & $0.039^{* *}$ & $0.107 * *$ & $0.057^{* *}$ \\
Gearing & $(0.110)$ & $(6.852)$ & $(3.484)$ & $(4.787)$ \\
Stock activity & -0.025 & $0.051^{* *}$ & $-0.072^{* *}$ & 0.013 \\
& $(-1.064)$ & $(9.984)$ & $(-3.484)$ & $(1.496)$ \\
D1997 & $-0.073^{* *}$ & $0.020^{* *}$ & $-0.067^{* *}$ & $0.018^{* *}$ \\
& $(-3.631)$ & $(4.139)$ & $(-2.951)$ & $(2.719)$ \\
$\bar{R}^{2}$ & $-0.061 * *$ & & $-0.085^{* *}$ & \\
S.E. of regression & $(3.677)$ & & $(-5.318)$ & 0.993 \\
Observations & 0.886 & 0.998 & 0.863 & 0.072 \\
\hline
\end{tabular}

Notes: t-values in parentheses. White heteroskedasticity-consistent standard errors and covariance and GLS (cross-section weights). ** Significant at $1 \%$ level . * Significant at $5 \%$ level

\section{Appendix (1) \\ Rarely or never disclosed items}

Group A: general information

1.9 Market share.

1.10 Geographic segment.

1.13 Future plans.

\section{Group B: income statement}

2.10 Non-operating gains or losses.

2.14 Minority interests.

2.16 Effect of significant changes in accounting estimates.

2.17 Fundamental errors and how they are treated.

2.18 Effect of significant changes in accounting

\section{Group C: balance sheet}

3.18 Classification of loans.

3.22 Changes in equity accounts during the year.

3.23 Priorities to preferred shares as to dividends.

3.24 Accumulated preferred dividends due.

3.25 Number and cost of treasury stock

3.26 Paid in capital in excess of par value

\section{Group D: cash flow statement}

4.1 Operating activities disclosed according to direct/indirect method.

4.8 Cash flow related to purchase/sale of interest in holding subsidiary and associated companies. 
4.11 Balances of cash \& cash equivalents that are not available for use.

4.12 Amount of facilities available for the company but not used yet.

4.13 Cash flow representing increase in operating capacity disclosed separately from that representing maintenance of current operating capacity.

4.14 Disclosing the necessary reconciliation if the balances appearing in the cash flow statement are different from the corresponding balances appearing in the balance sheet.

\section{Group E: accounting policies}

5.3 Research \& development costs.

5.4 Pension costs.

5.5 Reasons for extraordinary items.

5.7 Acquisition method.

5.8 Treatment of intangible assets.

5.10 Outside manager of pension funds.

5.13 Discretionary reserves.

5.14 Minority interest.

5.15 Contingent liabilities.

5.18 Long-term contracts long-term leases capital leases sales on instalments and related interest.

5.19 Events after the balance sheet date.

5.20 The policy used for determination of cash $\&$ cash equivalents.

\section{Group F: stockholders information}

6.5 Stock split / dividend / right issues.

6.6 Stock prices.

6.7 Trading volumes.

6.8 Diluted earnings per share.

\section{Group G: supplementary information}

7.4 Disclosure of subsequent events. 7.8 Qualitative and quantitative forecasts of revenues expenses profits and cash flows. 7.9 Assumptions underlying forecasts. 7.10 Schedule of interest and principal due on long-term debt in future years.

\author{
Appendix (2) \\ List of items of information ${ }^{1}$ \\ Group A: general information \\ 1.1 Company name. \\ 1.2 Address, telephone, fax. \\ 1.3 The currency used for the preparation of \\ financial statements. \\ 1.4 Company legal status. \\ 1.5 Purpose of the company's activity. \\ 1.6 The period covered by financial statement
}

\footnotetext{
${ }^{1}$ Underlined items of information are items that are treated as voluntary, the rest are mandatory. Highlighted items of information are items drawn from CIFAR checklist.
}

1.7 List of board members and their

affiliations.

$\underline{1.8 \text { Number of employees. }}$.

1.11 Business segment.

1.12 Comparative financial statements

1.14 Board of directors' report.

Group B: income statement

2.1 Sales or turnover

2.2 Credit interest.

2.3 Non-operating revenues.

2.4 Cost of good sold.

2.5 Selling general and administrative expenses.

2.6 Operating income.

2.7 Interest expense.

2.8 Income tax expense.

2.9 Non-operating expenses

2.11 Foreign exchange gains or losses.

2.12 Depreciation \& amortization expenses.

2.13 Net income.

2.15 Effect of transactions with related parties: holding, subsidiary, and associated companies

\section{Group C: balance sheet}

3.1 Classification of assets to long-term assets and current assets.

3.2 Classification of liabilities to long-term liabilities and short-term liabilities.

3.3 Owners' equity separated from liabilities.

3.4 Separation of reserves and retained earnings.

3.5 Cash and cash equivalents.

3.6 Inventories reported.

3.7 Accounts receivables.

3.8 Classification of other receivables.

3.9 Investment in each subsidiary \& associated company.

3.10 Other investments and their market values if different from book value.

3.11 Items and values of intangible assets.

3.12 Investments in projects under construction.

3.13 The value of each item of fixed assets and its accumulated depreciation.

3.14 Total assets can be derived.

3.15 Restrictions on ownership of assets.

3.16 Classification of short-term liabilities.

3.17 Classification of long-term liabilities.

3.19 Classification of provisions

3.20 Number of issued shares and par value per share.

3.21 The paid amount of capital.

3.27 Classification of reserves.

3.28 Retained earnings.

\section{Group D: cash flow statement}

4.2 Disclosing the necessary reconciliation of net income when the indirect method is used. 
4.3 Main items of cash inflow from different activities.

4.4 Main items of cash outflow from different activities.

4.5 Net cash flow from different activities.

4.6 Cash flow related to interests, dividends, and extraordinary items disclosed separately. 4.7 Cash outflow for taxes.

4.9 Non-cash investment and finance transactions disclosed separately.

4.10 Breakdown of cash \& cash equivalents.

\section{Group E: accounting policies}

5.1 Accounting standards.

5.2 Financial statements cost basis.

5.6 Inventory physical count $\&$ valuation.

5.9 Taxation.

$\underline{5.11 \text { Foreign currency transaction method. }}$

5.12 Foreign currency transaction gains or $\underline{\text { losses. }}$
5.16 Treatment of investments.

5.17 Revenue recognition basis.

Group F: stockholders information

6.1 Earnings distribution statement.

6.2 Earnings per share

6.3 Total dividends.

6.4 Dividends per share.

6.9 Composition of shareholdings.

$\underline{6.10 \text { Significant shareholders. }}$

Group G: supplementary information

7.1 Earning per share numerator.

7.2 Earnings per share denominator.

7.3 Notes to accounts.

7.5 Remuneration of board of directors.

7.6 Exports.

7.7 Financial ratios disclosed.

7.11 Auditor's report. 
Appendix 3 T- test for equality of means per item of information

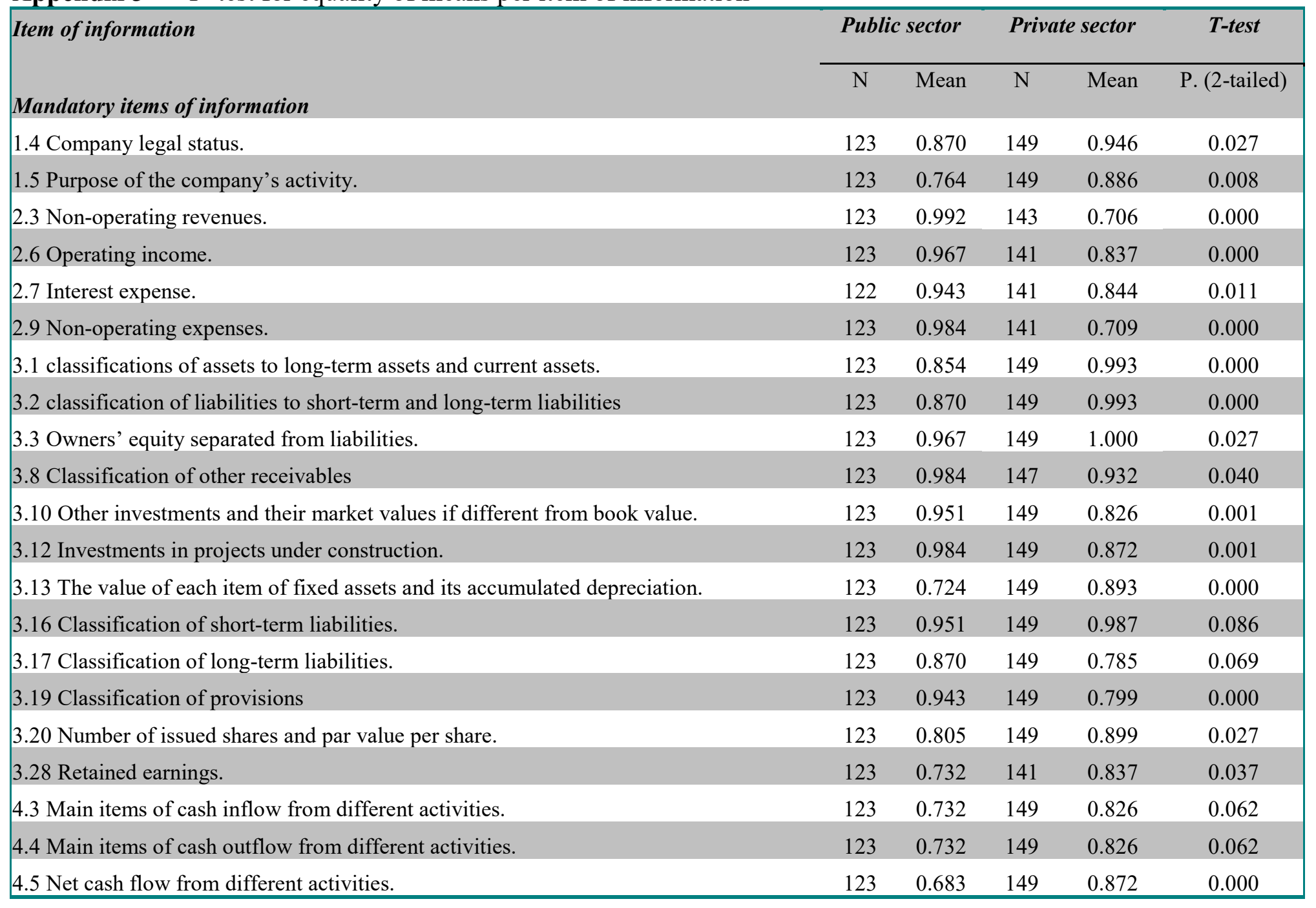




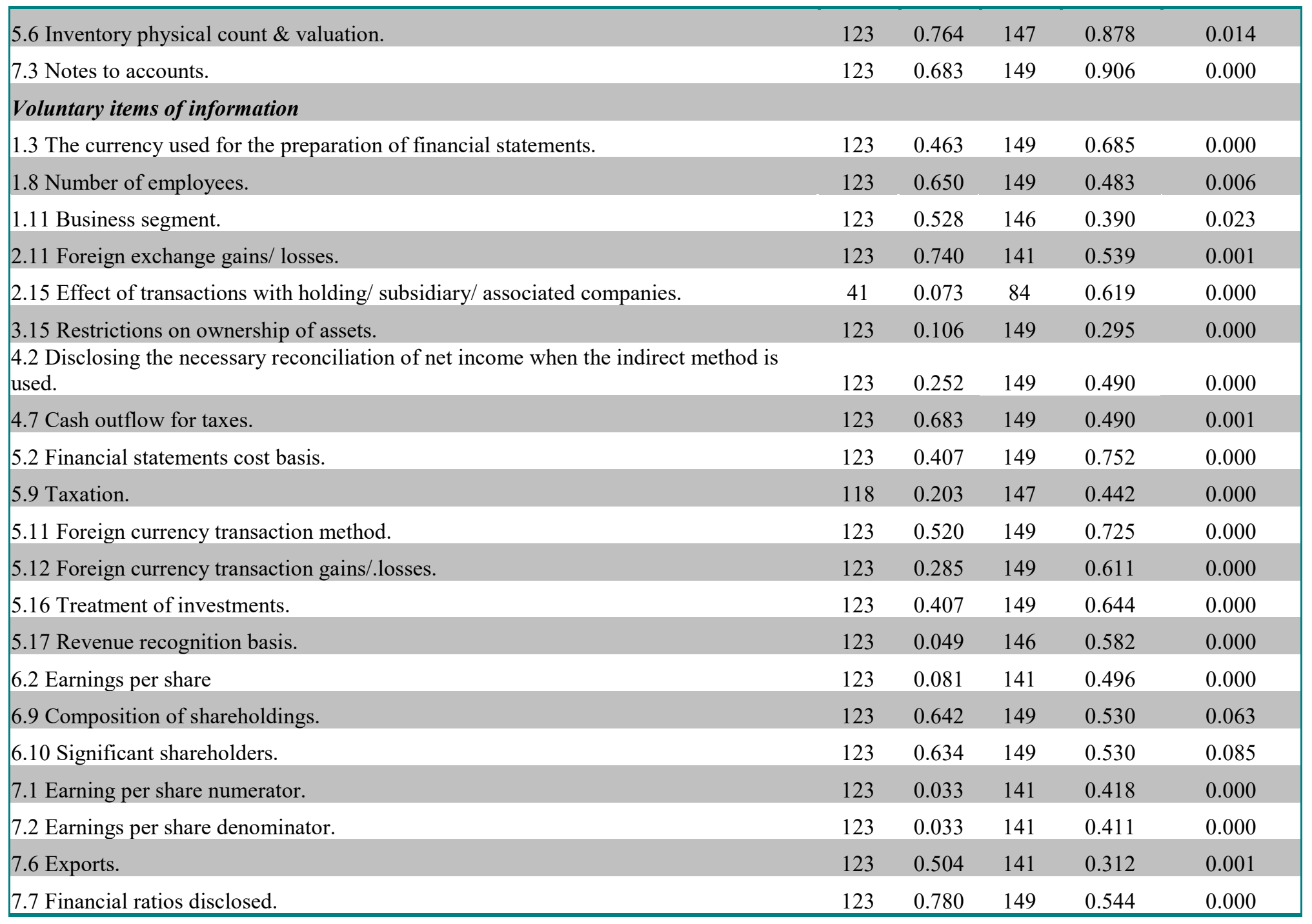




\section{References and notes}

1. Hsiao, C. (1986) 'Analysis of Panel Data', Cambridge University Press, Cambridge, NY.

2. Abd-Elsalam, O. H. and Weetman, P. (2003) 'Introducing international accounting standards to an emerging capital market: relative familiarity and language effect, with a case study of Egypt', Journal of International Accounting, Auditing and Taxation, Vol. 12, Issue 1, pp. 63-84

3. Abd-Elsalam, O. H. (1999) 'The Introduction And Application Of International Accounting Standards To Accounting Disclosure Regulations Of A Capital Market In A Developing Country: The Case Of Egypt', PhD Thesis, Heriot-Watt University, Edinburgh, UK.

4. Ministerial Decree No. $503 / 1997$.

5. There are different ways for companies to disclose information, among which annual reports are considered a very important official source of information. Disclosure information in annual reports can be divided into two broad categories, mandatory and voluntary. Mandatory disclosure is information revealed to comply with the requirements of statute in the form of laws, professional regulations in the form of standards, and the listing rules of stock exchanges. Voluntary disclosure is any information in excess of the mandated disclosure. The problem is how to measure disclosure information given that disclosure is a theoretical concept that is difficult to measure directly. For details see: Marston, C. L. and Shrives, P.J. (1991) 'The use of disclosure indices in accounting research: a review article', British Accounting Review, Vol.23, pp.195-210.

6. CMA is the market regulatory agency responsible for ensuring the development of a transparent and secure market for investors in Egypt. The CMA monitors market activity and facilitates capital growth by requiring disclosure, encouraging more secure institutions for trading securities, and promoting the introduction of markets for new investment instruments http://www.cma.gov.eg/En-nf/index1.html (Accessed 07 August 2003).

7. Report on the Observance of Standards and Codes (ROSC), Corporate Governance Country Assessment, (2004), Egypt.

8. Report on the Observance of Standards and Codes (ROSC), Accounting and Auditing, (2002), Egypt.

9. Ahmed, K. and Nicholls (1994) 'The impact of non-financial company characteristics on mandatory disclosure compliance in developing countries: the case of Bangladesh', The International Journal of Accounting, Vol. 29, pp. $62-77$.

10. The literature on disclosure to date provides two measurement techniques: financial analysts' perceptions about firm disclosure practices, and content 
analysis technique (either electronically or manually). Regardless of the advantages and disadvantages of financial analysts' perceptions about firm disclosure practices and the electronic content analysis, the manual content analysis (traditional disclosure index approach) proves to be the most suitable research method to investigate disclosure levels in the Egyptian context. This is because perceptions of financial analysts about firm disclosure practices have not yet been introduced for listed companies in Egypt, and the original annual reports available for this research are images files in the Arabic language, which cannot be searched using electronic software originally designed for searching English text files. Hence, the traditional content analysis is the most suitable technique for this paper.

11. Center for International Financial Analysis and Research (CIFAR), (1995) International Accounting and Auditing Trends', Fourth edition, (edited by V.Bavishi) Princeton, NJ.

12. Hope, O.-K. (2003) 'Disclosure practices, enforcement of accounting standards and analysts' forecast accuracy: an international study', Journal of Accounting Research, Vol. 41, No.2, (May), pp.235-272

13. Morris, R.D. (1987) 'Signaling, agency theory and accounting policy choice', Accounting and Business Research, Vol.18, no.69, pp.47-56.

14. Depoers, F. (2000) 'A-cost-benefit study of voluntary disclosure: some empirical evidence from French listed companies', The European Accounting Review, Vol. 9, No. 2, pp. 245-263.

15. AW [2] identify three proxies for disclosure level: the international accounting standards disclosure requirements which were already familiar through the CA of 1981 (IAS-CA), the international disclosure requirements which were appended to the CML of 1992 in Arabic language (IAS-CML), and the international accounting standards disclosure requirements which had not been available in an official Arabic translation (IAS-NA).

16. Inchausti, B. G. (1997) 'The influence of company characteristics and accounting regulation on information disclosed by Spanish firms', The European Accounting Review, Vol. 6, No.1, pp. 45-68.

17. Skinner, D. (1994) 'Why firms voluntarily disclose bad news', Journal of Accounting Research, Vol.32, No.1, pp.38-60, (Spring).

18. Elsadik [19], and results from an unpublished study by Hassan. Hassan finds that investors in Egypt pay much attention to income and dividends figures when making investment decisions, where operating income is the most useful item of information followed by dividends per share and net income.

19. Elsadik, Z. (1990) 'Re-organizing the accounting and auditing profession in the Arab Republic of Egypt', Paper presented at the second Conference of the Scientific Association of Accounting Systems and Auditing, Horizons of 
Accounting Developments in Egypt, Cairo 24/25 April (paper in Arabic). Cited in [3].

20. Chow, C.W. and Wong-Boren, A. (1987) 'Voluntary financial disclosure by Mexican corporations', The Accounting Review, Vol.62, No. 3, (July), pp.533541.

21. It was decided to use as the starting date the year when the ESE started its revival (1992). However, the CMA could only offer information about share prices from 1995.

22. Furthermore, the sample includes companies with two different financial yearends, one in June and the other in December. This inclusion of different yearends will not affect the results of this research, since we do not expect the financial year-end to affect level of disclosure.

23. Naser, K. and Nuseibeh, R. (2003) 'Quality of financial reporting: evidence from the listed Saudi nonfinancial companies' The International Journal of Accounting, Vol. 38, pp. 41-69.

24. Maddala, G.S. (2002) 'Introduction To Econometrics', Third Edition, John Wiley \& Sons, LTD, NY.

25. Chow and Wong-Boren [20] state that a statistically significant correlation of 0.34 does not suggest a serious collinearity problem.

26. Groebner, D. F., Shannon, P.W., Fry, P.C. and Smith, K.D. (2005) 'Business Statistics- A Decision-making Approach', NJ, International edition, Pearson Prentice Hall.

27. Tolerance is $1-\mathrm{R}^{2}$ for the regression of each explanatory variable on all the other explanatory variables. There will be as many tolerance coefficients as there are explanatory variables. The higher the inter-correlation of the explanatory variables, the more the tolerance will approach zero. As a rule of thumb, if tolerance is less than .20 , then a problem with multicollinearity is indicated. http://www2.chass.ncsu.edu/garson/pa765/regress.htm (Accessed 09 November 2004).

28. Gujarati, D. N. (1995) 'Basic Econometrics', Third edition, Lisbon, London, McGraw-Hill International Editions, Economic Series, McGraw-Hill, INC.

29. It is worth noting that the relationship between voluntary disclosure level and profitability was negative but not significant: however, introducing the 1997 dummy variable into the model changed the sign to a positive but not significant one. Moreover, the introduction of the year 1997 dummy did not affect the significance or the direction of the relationships with the other explanatory variables. 
30. In GLS we minimize a weighted sum of residual squares (weight $=1 / \sigma_{i}^{2}$ ). The weight assigned to each observation is inversely proportional to its $\sigma_{\mathrm{i}}$, that is observations coming from a population with larger $\sigma_{i}$ will get relatively smaller weight and those from a population with smaller $\sigma_{\mathrm{i}}$ will get proportionately larger weight. This means that extreme observations will get relatively smaller weight than the other observations in GLS, while they will dominate in OLS $[28,364]$. Thus GLS will tend to increase the adjusted Rsquared.

31. Groebner at al. [26, 564:565] state that: 'The standard deviation of the regression model measures the dispersion of the observed dependent variable around values predicted by the regression model. It is the square root of the mean square error of the residuals. Sometimes, even though a model has a high $\mathrm{R}^{2}$, the estimate of the standard deviation of the model error will be too large to provide adequate precision for confidence and prediction intervals. A rule of thumb that we have found useful is to examine the range $\pm 2 \mathrm{~S}_{\varepsilon}$. If this range is acceptable from a practical viewpoint, the estimate of the standard deviation of the model error might be considered acceptable'.

32. 